\title{
Are Latin American ecologists recognized at the world level? A global comparison
}

\author{
Jaime R. Rau ${ }^{1 *}$ (D) and Fabian M. Jaksic ${ }^{2}$
}

\begin{abstract}
Background: loannidis et al. (2020) reported a standardized estimate of scientific productivity obtained from a worldwide database of 6,880,389 scientists who published at least 5 papers picked up by the Scopus database, and elaborated a ranking of ca. 120,000 scientists by both whole trajectory (career-long) impact and their current impact at year 2019. The goal of our paper is to contextualize Latin American ecologists' contribution at the world level based on the four most scientifically productive countries in the region.

Methods and findings: loannidis et al. (2020) proposed a composite index that is the sum of six scientometric indicators: (1) The number of allocites, (2) the $h$ index, (3) a per capita corrected version of $h$, (4) the allocites received as single author, (5) those received as single + first author, and (6) those as single + first + last author. We selected data for ecologists from Argentina, Brazil, Chile, and Mexico and comparatively analyzed their productivity according to the proposed index. We also compared these data with those obtained from a global sample of the top ecologists worldwide.
\end{abstract}

Conclusions: Based on loannidis et al.'s proposition to evaluate scientific productivity we extract three lessons: (1) It does not pay to publish many papers; what counts is the number of allocites (i.e., self-citations do not add up). (2) Either be single, first, or last author; it does not pay to be in the middle of an authorship line. (3) Even worse it is to be among many co-authors because the proposed index allocates credits on a per capita basis.

Keywords: Productivity, Scientometrics, loannidis index, Allocites, Self-citation, Brazil, Mexico, Argentina, Chile

\section{Background}

Scientific productivity refers to the productivity of scientists in their research performance. In other words, the term concerns how much output scientists produce within a certain time period, which enables comparisons among them. Based on first authors who published in journals indexed by the Web of Science database, the four most scientifically productive Latin American countries in 2017 were: Brazil, Argentina, Mexico, and Chile, in decreasing order, together accounting for $9.3 \%$ of the world production [1]. A more current study [2] shows that the descending sequence is now: Brazil, Mexico, Argentina, and Chile. Here, we study the scientific

\footnotetext{
* Correspondence: jrau@ulagos.cl

'Laboratorio de Ecología, Departamento de Ciencias Biológicas y

Biodiversidad, Universidad de Los Lagos, Campus Osorno, Osorno, Chile Full list of author information is available at the end of the article
}

productivity of these four countries on a worldwide comparison, based on the results of the recent review paper by Ioannidis et al. [3], wherein these authors reported a database built with an extensive sample of ca. 120,000 scientists from a worldwide universe of $6,880,389$ who published at least five articles indexed in the Scopus database (stored at the Mendeley web site). Toward this, they considered 22 disciplinary areas and 176 sub-disciplines, and elaborated a ranking of scientists by both whole trajectory (career-long) impact and their current impact at year 2019, using a productivity index of their own design.

It is hence tempting to assess the Latin American contribution to world science of any discipline, but by reason of academic interest we choose to concentrate on the contribution and accomplishments in the Ecological sub-discipline. Thus, the goal of this paper is to contextualize

(c) The Author(s). 2021 Open Access This article is licensed under a Creative Commons Attribution 4.0 International License, which permits use, sharing, adaptation, distribution and reproduction in any medium or format, as long as you give

appropriate credit to the original author(s) and the source, provide a link to the Creative Commons licence, and indicate if changes were made. The images or other third party material in this article are included in the article's Creative Commons licence, unless indicated otherwise in a credit line to the material. If material is not included in the article's Creative Commons licence and your intended use is not permitted by statutory regulation or exceeds the permitted use, you will need to obtain permission directly from the copyright holder. To view a copy of this licence, visit http://creativecommons.org/licenses/by/4.0/. 
Latin American ecologists' contribution at the global level, thus possibly aiding public-policy decisionmaking, including categorization, prioritization, and financing of research and researchers.

\section{Methods}

To obtain their metrics, Ioannidis et al. [3] used a composite index that is the sum of the decimal logarithms of six scientometric indicators that include: (1) The number of allocites (NC, cites excluding self-citation); (2) the $h$ index (H, Hirsch 2005, 2007); (3) a corrected version of it ( $\mathrm{Hm},[4]$; it is $\mathrm{H}$ based on a fractionalized counting of papers according to the number of co-authors); (4) the allocites received by quality of authorship as single author (NCS); (5) those received as single + first author (NCSF); and (6) those as single + first + last author (NCSFL).

The formula to calculate the composite indicator for career-long impact or single-year (2019) impact is obtained by summing the ratio of $\log$ of $1+$ the indicator value over the maximum of those indicator logs for the 6 indicators (see [3] for details). All summands are equally weighted $(=1)$. Notice that total production of papers is not an addend in this formula, that total citations received contribute to the $\mathrm{H}$ and $\mathrm{Hm}$ personal indices indirectly, and directly to the three NC's --but only if they are received as single, first, or last author of a paper. Authors with only co-authorships, not leading or trailing an authorship line, will add zero in these three summands $(=\log$ of 1$)$.

Allocites are quotations that other authors make about the work of a specific author [5]. To find out the identity and productivity of the ecologists of the currently four most productive Latin American countries, we filtered the Excel spreadsheets of Tables S-6 and S-7 of Ioannidis et al. [3], first by country, and then by discipline (Biology) and sub-disciplines. We used only the term "Ecology" as the sub-discipline of interest. For comparative purposes, we used information from those two tables to build a global sample of the most productive ecologists in the world, with sample size set up by the largest and most populous Latin American country, Brazil.

\section{Results}

The list of ecologists and their scientometric parameters (position in the whole trajectory rank, No. allocites, No. papers) with institutional addresses in any of the four most scientifically productive Latin American countries is in Table 1. Also shown are those ecologists from the developed world that rank highest in a global sample of 16 scientists, equivalent to the largest Latin American country sample. Specifically, Brazil was represented by 16 ecologists (one female), followed by 9 from Chile (no females), 8 from Argentina (two females), and 3 from Mexico (one female). In the global sample, 9 were from the US, 6 from the EU, and one from Singapore (no females were represented).

Ranges of the three scientometric parameters show (Table 2) that Brazil rankings start at position 3000, Argentina at 16,000, Chile at 20,000, and Mexico at 30,000 . They all end at about position 110,000. The broadest range in allocites is found in Chile and the narrowest in Mexico. Brazil is the country that published the most papers, followed by Chile. In the global sample, about 1000 papers were published.

Using data from Table 1, coefficients of variation, CV (\%), were generated for each parameter and shown in Table 3. Brazil and the global sample yielded the lowest CVs in ranking, while Chile and Argentina showed higher variability in No. allocites and No. papers.

Table 4 presents the same scientometric parameters as in Table 1, but this time for 2019 only. In this case, the global sample is made up of 31 ecologists (those found in the largest Latin country sample, Brazil). Among the Brazilians, only three are females. Argentina yields 13 ecologists (two females), followed by Chile with 10 (no females), and Mexico with 6 (one female). The global sample yielded only one female among the 31 ecologists: 12 of these from the US, 9 from the EU, 5 from Australia, 4 from Canada, and 1 from New Zealand. Although there are relatively fewer US ecologists in this sample as compared to the Career-long sample of 16 ecologists (Table 1), there was no significant difference in frequencies between them (Chi-square $=0.252$; $P=0.355)$.

Ranges of the three scientometric parameters show (Table 5) that Brazil comes first in single-year (2019) ranking, followed by Argentina. Broadest ranges of allocites are found in the global sample, from 1000 to 10,000 while the four Latin American countries are rather homogenous among them. No. papers ranged 100 to 1000 globally while Latin American countries were less variable in this respect.

Coefficients of variation for each single-year parameter are shown in Table 6. Chile yielded the lowest and Mexico the highest CVs in 2019-ranking. CV for No. allocites was narrowest in Brazil and broadest in Mexico, exactly the opposite for CV in No. papers. No pattern was detected for $\mathrm{CVs}$ in the global sample.

By comparing Tables 1 and 4 it is evident that the number of researchers increased, with new names added in 2019 that were not detected in the whole-trajectory ranking, and with some career-long researchers disappearing from the 2019 parameter estimates. In Brazil, 15 new ecologists were detected while one long-career disappeared. In Mexico, four were added and one disappeared; in Argentina, five new with none disappearing; 
Table 1 Whole trajectory (Career-long) impact ranking of Latin American ecologists, No. allocites, and No. papers in the Scopus database, based on Table S-6, Career-long ranking, by loannidis et al. [3]. Here and elsewhere countries in decreasing order by total population size (Table 7). For the global sample, countries are identified by their ISO 3166 Codes

\begin{tabular}{|c|c|c|c|}
\hline Ecologists & Career-long rank & $\mathrm{N}^{\circ}$ allocites & $\mathrm{N}^{\circ}$ papers \\
\hline \multicolumn{4}{|l|}{ Brazil } \\
\hline Fearnside, Philip Martin & 3804 & 10,675 & 237 \\
\hline Diniz-Filho, José A. F. & 30,832 & 10,388 & 337 \\
\hline Junk, Wolfgang J. & 30,938 & 4736 & 126 \\
\hline Metzger, Jean Paul & 39,906 & 7208 & 136 \\
\hline Galetti, Mauro & 57,379 & 6426 & 176 \\
\hline Vasconcelos, Heraldo L. & 61,500 & 5586 & 138 \\
\hline Fernandes, Geraldo W. & 63,217 & 4994 & 359 \\
\hline Magnusson, William E. & 75,881 & 5026 & 225 \\
\hline Martinelli, Luiz A. & 77,082 & 12,480 & 225 \\
\hline Pillar, Valerio D. & 87,368 & 4447 & 150 \\
\hline Bini, Luis Mauricio & 87,806 & 7925 & 217 \\
\hline Oliveira-Filho, Ary T. & 91,374 & 3738 & 94 \\
\hline Oliveira, Paulo S. & 95,680 & 2482 & 99 \\
\hline Begossi, Alpina & 96,919 & 2079 & 87 \\
\hline Escarano, Fabio R. & 101,871 & 2215 & 101 \\
\hline Tabarelli, Marcelo & 110,477 & 4861 & 134 \\
\hline \multicolumn{4}{|l|}{ Mexico } \\
\hline Morrone, Juan J. & 29,903 & 3756 & 178 \\
\hline Ceballos, Gerardo & 49,596 & 6803 & 124 \\
\hline Williams-Linera, Guadalupe & 96,735 & 1901 & 65 \\
\hline \multicolumn{4}{|l|}{ Argentina } \\
\hline Diaz, Sandra & 16,779 & 24,616 & 168 \\
\hline Aizen, Marcelo A. & 24,268 & 8957 & 131 \\
\hline Paruelo, José & 52,361 & 17,020 & 167 \\
\hline Vázquez, Diego P. & 56,310 & 5228 & 71 \\
\hline Austin, Amy T. & 72,262 & 4951 & 64 \\
\hline Morales, Juan M. & 92,256 & 3791 & 82 \\
\hline Oesterheld, Martín & 93,268 & 8529 & 79 \\
\hline Kitzberger, Thomas & 96,056 & 6905 & 102 \\
\hline \multicolumn{4}{|l|}{ Chile } \\
\hline Castilla, Juan Carlos & 22,950 & 38,925 & 92 \\
\hline Thiel, Martin & 30,033 & 6697 & 232 \\
\hline Bozinovic, Francisco & 37,534 & 13,340 & 271 \\
\hline Niemeyer, Hermann M. & 45,942 & 4470 & 243 \\
\hline Jaksic, Fabián M. & 50,576 & 7306 & 137 \\
\hline Marquet, Pablo A. & 60,565 & 3642 & 162 \\
\hline Santelices, Bernabé & 71,212 & 14,151 & 96 \\
\hline Gianoli, Ernesto & 95,480 & 9161 & 146 \\
\hline Navarrete, Sergio A. & 100,707 & 1829 & 124 \\
\hline
\end{tabular}


Table 1 Whole trajectory (Career-long) impact ranking of Latin American ecologists, No. allocites, and No. papers in the Scopus database, based on Table S-6, Career-long ranking, by loannidis et al. [3]. Here and elsewhere countries in decreasing order by total population size (Table 7). For the global sample, countries are identified by their ISO 3166 Codes (Continued)

\begin{tabular}{|c|c|c|c|c|}
\hline Ecologists & & Career-long rank & $\mathrm{N}^{\circ}$ allocites & $\mathrm{N}^{\circ}$ papers \\
\hline Global sample & Country & & & \\
\hline Tilman, David & US & 63 & 81,754 & 274 \\
\hline Møller, Anders Pape & $\mathrm{FR}$ & 171 & 38,556 & 952 \\
\hline Gaston, Kevin J. & $\mathrm{GB}$ & 251 & 47,195 & 638 \\
\hline Vitousek, Peter M. & US & 265 & 54,644 & 290 \\
\hline Reich, Peter B. & $\mathrm{AU}$ & 377 & 61,267 & 635 \\
\hline Carpenter, Stephen R. & US & 432 & 69,414 & 399 \\
\hline Chapin, F. Stuart & US & 562 & 72,218 & 431 \\
\hline Shine, Richard & $\mathrm{AU}$ & 573 & 29,081 & 952 \\
\hline Ricklefs, Robert E. & US & 603 & 22,516 & 365 \\
\hline Hanski, Ilkka & $\mathrm{Fl}$ & 612 & 23,686 & 271 \\
\hline Levin, Simon A. & US & 630 & 34,367 & 405 \\
\hline Wardle, David A. & SG & 700 & 40,086 & 331 \\
\hline Simberloff, Daniel & US & 705 & 30,301 & 285 \\
\hline Brown, James $\mathrm{H}$. & US & 708 & 38,873 & 262 \\
\hline Körner, Christian & $\mathrm{CH}$ & 722 & 24,280 & 339 \\
\hline Holt, Robert D. & US & 754 & 33,481 & 263 \\
\hline
\end{tabular}

and in Chile, four new appeared and three long-careers disappeared. In the global sample, 18 were added and four disappeared.

Given the contrasting population sizes of the four Latin American countries being compared, some form of standardization is mandatory. We chose the number of ecologists (obtained from Tables 1 and 4) per million inhabitants. This calculation done, it is clear that the smallest countries (Argentina and Chile) have more per capita ecologists than the largest ones (Brazil and Mexico) (Table 7).

\section{Discussion}

Extracting information on the estimate of the population sizes of these countries for the year 2020 (http://www. wikipedia.org), and the number of ecologists from Table

Table 2 Ranges of scientometric indicators, with regard to position in the Whole trajectory (Career-long) impact ranking, No. allocites, and No. papers in the Scopus database, for the most scientifically productive countries in Latin America (from Table-S6, Career-long ranking, by loannidis et al. [3])

\begin{tabular}{llll}
\hline Countries & Career-long Rank & No. allocites & No. papers \\
\hline Brazil & $3804-110,477$ & $2079-12,480$ & $87-359$ \\
Mexico & $29,903-96,735$ & $1901-6803$ & $65-178$ \\
Argentina & $16,779-96,056$ & $3791-24,616$ & $64-168$ \\
Chile & $22,950-100,707$ & $1829-38,925$ & $92-271$ \\
Global sample & $63-754$ & $22,516-81,754$ & $262-952$ \\
\hline
\end{tabular}

S-6 for the whole-trajectory impact index, and from Table S-7 for the annual 2019 rank of the paper by Ioannidis et al. [3], it can be corroborated in Table 7 that the sequence of these countries is reversed if the data are expressed as the number of ecologists per million inhabitants. In such analysis, Chilean and Argentinian ecologists occupy the first and second per capita place followed by Brazilian and Mexican ecologists. Interestingly, Chile currently ranks second after Brazil in Latin America when it comes to publication in high-impact mainstream journals (https://www.natureindex.com/ annual-tables/2019/country/all).

On the other hand, while Brazilian ecologists may not publish in the highest-ranking journals, they do attract abundant citations (see [6]). Noteworthy is the place occupied by Mexico in the whole-trajectory ranking, with

Table 3 Coefficients of variation, CV (\%), with regard to position in the Whole trajectory (Career-long) impact ranking, their associated No. allocites, and No. papers in the Scopus database, for the most scientifically productive countries in Latin America (from Table-S6, Career-long ranking, by loannidis et al. [3])

\begin{tabular}{llll}
\hline Countries & CV Rank & CV No. allocites & CV No. papers \\
\hline Brazil & 43.7 & 51.9 & 46.8 \\
Mexico & 58.5 & 59.6 & 46.2 \\
Argentina & 49.3 & 72.0 & 39.1 \\
Chile & 48.1 & 100.0 & 39.4 \\
Global sample & 43.2 & 43.0 & 52.0 \\
\hline
\end{tabular}


Table 4 Single-year (2019) impact ranking of Latin American ecologists, their No. allocites, and No. papers in the Scopus database (from Table S-7, 2019 Single-year ranking, by loannidis et al. [3]). For the global sample, countries are identified by their ISO 3166 Codes

\begin{tabular}{|c|c|c|c|}
\hline Ecologists & 2019 Rank & $\mathrm{N}^{\circ}$ allocites & $\mathrm{N}^{\circ}$ papers \\
\hline \multicolumn{4}{|l|}{ Brazil } \\
\hline Fearnside, Philip Martin & 3171 & 1444 & 237 \\
\hline Metzger, Jean Paul & 17,850 & 1585 & 136 \\
\hline Diniz-Filho, José A. F. & 19,583 & 1576 & 337 \\
\hline Galetti, Mauro & 25,181 & 1962 & 176 \\
\hline Junk, Wolfgang J. & 26,289 & 619 & 126 \\
\hline Phalan, Benjamin T. & 30,627 & 850 & 69 \\
\hline Fernandes, Geraldo W. & 30,783 & 982 & 359 \\
\hline Pardini, Renata & 41,288 & 737 & 71 \\
\hline Soares-Filho, Britaldo S. & 46,309 & 1361 & 98 \\
\hline Aragão, Luiz E.O.C. & 49,214 & 1566 & 164 \\
\hline Pillar, Valerio D. & 52,541 & 1120 & 150 \\
\hline Bini, Luis Mauricio & 54,287 & 1302 & 217 \\
\hline Tabarelli, Marcelo & 58,953 & 1016 & 134 \\
\hline Martinelli, Luiz A. & 61,856 & 1878 & 225 \\
\hline Vasconcelos, Heraldo L. & 64,916 & 812 & 138 \\
\hline Oliveira-Filho, Ary T. & 69,133 & 618 & 94 \\
\hline Loyola, Rafael & 69,630 & 851 & 129 \\
\hline Escarano, Fabio R. & 72,267 & 462 & 101 \\
\hline Ladle, Richard J. & 72,980 & 969 & 150 \\
\hline Rangel, Thiago Fernando & 77,389 & 788 & 106 \\
\hline Magnusson, William E. & 81,307 & 1004 & 225 \\
\hline De Marco Jr., Paulo & 82,760 & 607 & 146 \\
\hline Jenkins, Clinton N. & 86,536 & 1405 & 58 \\
\hline Begossi, Alpina & 87,957 & 351 & 87 \\
\hline Lewinsohn, Thomas M. & 90,482 & 497 & 73 \\
\hline Morellato, Leonor P. C. & 93,616 & 506 & 111 \\
\hline Brancalion, Pedro H.S. & 98,574 & 891 & 138 \\
\hline Strassburg, Bernando & 103,510 & 728 & 55 \\
\hline Schøngart, Jochen & 106,591 & 570 & 62 \\
\hline Ribeiro, Milton C. & 106,903 & 820 & 108 \\
\hline Werneck, Fernanda P. & 122,234 & 237 & 38 \\
\hline \multicolumn{4}{|l|}{ Mexico } \\
\hline Morrone, Juan J. & 10,511 & 612 & 178 \\
\hline Ceballos, Gerardo & 13,381 & 1741 & 124 \\
\hline Balvanera, Patricia & 45,671 & 1842 & 84 \\
\hline Villaseñor, Jose L. & 66,672 & 344 & 143 \\
\hline Valiente-Banuet, Alfonso & 83,635 & 558 & 102 \\
\hline MacGregor-Fors, Ian & 104,564 & 433 & 78 \\
\hline \multicolumn{4}{|l|}{ Argentina } \\
\hline Diaz, Sandra & 6877 & 5484 & 168 \\
\hline Aizen, Marcelo A. & 14,021 & 1565 & 131 \\
\hline
\end{tabular}


Table 4 Single-year (2019) impact ranking of Latin American ecologists, their No. allocites, and No. papers in the Scopus database (from Table S-7, 2019 Single-year ranking, by loannidis et al. [3]). For the global sample, countries are identified by their ISO 3166 Codes (Continued)

\begin{tabular}{|c|c|c|c|c|}
\hline \multicolumn{2}{|l|}{ Ecologists } & 2019 Rank & $\mathrm{N}^{\circ}$ allocites & $\mathrm{N}^{\circ}$ papers \\
\hline \multicolumn{2}{|l|}{ Jobbágy, Esteban G. } & 27,829 & 1740 & 143 \\
\hline \multicolumn{2}{|l|}{ Paruelo, José } & 30,087 & 2279 & 167 \\
\hline \multicolumn{2}{|l|}{ Austin, Amy T. } & 30,943 & 767 & 64 \\
\hline \multicolumn{2}{|l|}{ Vázquez, Diego P. } & 32,213 & 794 & 71 \\
\hline \multicolumn{2}{|l|}{ Morales, Juan M. } & 59,359 & 660 & 82 \\
\hline \multicolumn{2}{|l|}{ Garibaldi, Lucas A. } & 63,733 & 1128 & 85 \\
\hline \multicolumn{2}{|l|}{ Di Bitetti, Mario S. } & 65,338 & 396 & 70 \\
\hline \multicolumn{2}{|l|}{ Kitzberger, Thomas } & 69,215 & 1252 & 102 \\
\hline \multicolumn{2}{|l|}{ Grau, H. Ricardo } & 83,230 & 548 & 75 \\
\hline \multicolumn{2}{|l|}{ Oesterheld, Martín } & 91,394 & 1019 & 79 \\
\hline \multicolumn{2}{|l|}{ Farji-Brener, Alejandro G. } & 118,514 & 241 & 111 \\
\hline \multicolumn{5}{|l|}{ Chile } \\
\hline \multicolumn{2}{|l|}{ Thiel, Martin } & 13,539 & 2052 & 232 \\
\hline \multicolumn{2}{|l|}{ Castilla, Juan Carlos } & 29,417 & 862 & 192 \\
\hline \multicolumn{2}{|l|}{ Bozinovic, Francisco } & 35,041 & 788 & 271 \\
\hline \multicolumn{2}{|l|}{ Gianoli, Ernesto } & 49,810 & 591 & 146 \\
\hline \multicolumn{2}{|l|}{ Marquet, Pablo A. } & 54,350 & 1343 & 162 \\
\hline \multicolumn{2}{|l|}{ Fajardo, Alex } & 83,281 & 532 & 61 \\
\hline \multicolumn{2}{|l|}{ Gelcich, Stefan } & 86,820 & 636 & 111 \\
\hline \multicolumn{2}{|l|}{ Niemeyer, Hermann M. } & 130,755 & 266 & 243 \\
\hline \multicolumn{2}{|l|}{ Rezende, Enrico L. } & 140,786 & 373 & 72 \\
\hline \multicolumn{2}{|l|}{ Lara, Antonio } & 218,962 & 553 & 94 \\
\hline \multicolumn{2}{|l|}{ Global sample } & & & \\
\hline Tilman, David & US & 42 & 11,128 & 274 \\
\hline Reich, Peter B. & $\mathrm{AU}$ & 147 & 10,768 & 635 \\
\hline Folke, Carl & SE & 162 & 10,021 & 251 \\
\hline Gaston, Kevin J. & $\mathrm{GB}$ & 180 & 6879 & 638 \\
\hline Carpenter, Stephen R. & US & 230 & 10,295 & 399 \\
\hline Vitousek, Peter M. & US & 268 & 6133 & 290 \\
\hline Anderson, Marti J. & $\mathrm{NZ}$ & 350 & 3985 & 107 \\
\hline Legendre, Pierre & CA & 358 & 5719 & 311 \\
\hline Peñuelas, Josep & ES & 365 & 7869 & 691 \\
\hline Wardle, David A. & SG & 370 & 6431 & 331 \\
\hline Körner, Christian & $\mathrm{CH}$ & 426 & 3052 & 339 \\
\hline Farhrig, Lenore & CA & 447 & 3181 & 197 \\
\hline Costanza, Robert & $\mathrm{AU}$ & 473 & 5868 & 291 \\
\hline Asner, Gregory P. & US & 483 & 6572 & 513 \\
\hline Laurance, William & $\mathrm{AU}$ & 541 & 4968 & 385 \\
\hline Thuiller, Wilfried & $\mathrm{FR}$ & 551 & 6297 & 288 \\
\hline Berkes, Fikret & CA & 627 & 2619 & 205 \\
\hline Wu, Jianguo & US & 659 & 3695 & 262 \\
\hline Loreau, Michel & $\mathrm{FR}$ & 672 & 4749 & 269 \\
\hline
\end{tabular}


Table 4 Single-year (2019) impact ranking of Latin American ecologists, their No. allocites, and No. papers in the Scopus database (from Table S-7, 2019 Single-year ranking, by loannidis et al. [3]). For the global sample, countries are identified by their ISO 3166 Codes (Continued)

\begin{tabular}{lllll}
\hline Ecologists & & $\mathbf{2 0 1 9}$ Rank & $\mathbf{N}^{\circ}$ allocites & $\mathbf{N}^{\circ}$ papers \\
\hline Scheffer, Marten & NL & 710 & 6842 & 278 \\
Brown, James H. & US & 730 & 4011 & 262 \\
Holt, Robert D. & US & 744 & 4347 & 263 \\
Chapin, F. Stuart & US & 750 & 8941 & 431 \\
Levin, Simon A. & US & 762 & 4460 & 405 \\
Simberloff, Daniel & US & 764 & 3138 & 285 \\
Westoby, Mark & AU & 865 & 4984 & 250 \\
Hughes, Terry P. & AU & 945 & 4977 & 129 \\
Jackson, Robert B. & US & 965 & 3125 & 374 \\
Goulson, Dave & GB & 974 & 3757 & 282 \\
Kremen, Claire & CA & 1054 & 4496 & 156 \\
Poff, N. Le Roy & US & 1065 & 3548 \\
\hline
\end{tabular}

only three ecologists listed (Table 1 ). We speculate that the most recognized Mexican ecologists are currently affiliated to US institutions (e.g., Rodolfo Dirzo, José Sarukhán, Jorge Soberón). Contrary to expectations of a decline in the impact of global sample ecologists, in favor of fast-growing economies such as China, no support for that prediction was found by Smith et al. [6], based on 17 years of data for eight sub-disciplines, including Ecology.

Recently, Rau et al. [7] showed that ecologists from the four Latin American countries considered here currently publish (Web of Science database) a larger number of citable scientific documents but are nevertheless less cited than in the past. They hypothesized that this may be due to an asymmetry in the pattern of crosscitations: Latin Americans cite global ecologists more than expected but they receive fewer cites than expected. That is, there is no reciprocity in citations. To counteract this phenomenon in good faith would require that Latin Americans conduct research with local environmental and social relevance, but also with new methodologies and approaches; and with theoretical concepts

Table 5 Ranges of scientometric indicators, regarding position in the 2019 Single-year impact ranking, No. allocites, and No. papers in the Scopus database, for the most scientifically productive countries in Latin America (from Table-S7, 2019 Single-year ranking, by loannidis et al. [3])

\begin{tabular}{llll}
\hline Countries & 2019 Rank & No. allocites & No. papers \\
\hline Brazil & $3171-122,234$ & $237-1962$ & $38-359$ \\
Mexico & $10,511-104,564$ & $344-1842$ & $78-178$ \\
Argentina & $6877-118,514$ & $241-5484$ & $64-168$ \\
Chile & $13,539-218,962$ & $266-2052$ & $61-271$ \\
Global sample & $42-1065$ & $3052-11,128$ & $107-691$ \\
\hline
\end{tabular}

and principles of global interest, coupled with an increase in international collaboration (Anderson et al. [8], Rau et al. [9]). Of course, this strategy involves having sufficient institutional economic support and resources for the payment of publishing costs, which are higher in magazines of greater international impact (Rau \& Fuentes [10], Fontúrbel \& Vizentin-Bugoni [11]).

Another remarkable pattern is the low participation of female ecologists, both globally and at the Latin American level. This corresponds to the so called "Matilda effect" in science [12]. Gender bias in the refereeing process of Ecology and Evolution papers has been addressed but not found (e.g., [13]). Indeed, according to [14], citation rates of ecological papers are more affected by the study outcome with respect to the hypotheses tested, by article length, and by their country and university of affiliation, than by gender.

Understandably, Latin American productive ecologists not listed among the ca. 120,000 researchers ranked by Ioannidis et al. [3] may complain about the specifics of the impact ranking procedure. First, because total production of papers is not considered (only its first or

Table 6 Coefficients of variation, CV (\%), regarding position in the Single-year impact ranking-2019, No. allocites, and No. papers in the Scopus database for the most scientifically productive countries in Latin America (from Table-S7, 2019 Single-year ranking, by loannidis et al. [3])

\begin{tabular}{llll}
\hline Countries & CV 2019 Rank & CV No. allocites & CV No. papers \\
\hline Brazil & 47.0 & 46.0 & 54.8 \\
Mexico & 70.2 & 73.9 & 32.3 \\
Argentina & 61.7 & 99.0 & 35.8 \\
Chile & 34.3 & 66.4 & 47.0 \\
Global sample & 50.0 & 41.0 & 44.6 \\
\hline
\end{tabular}


Table 7 No. of ecologists in the four most scientificallyproductive Latin American countries (From Tables S-6 and S-7 by loannidis et al. [3]), standardized by population size

\begin{tabular}{llll}
\hline Countries & $\mathbf{N}^{\circ}$ people & $\begin{array}{l}\mathbf{N}^{\circ} \text { Career-long } \\
\text { ecologists/million }\end{array}$ & $\begin{array}{l}\mathbf{N}^{\circ} \text { Single-year } \\
\text { ecologists/million }\end{array}$ \\
\hline Brazil & $212,216,052$ & 0.07 & 0.15 \\
Mexico & $126,014,024$ & 0.02 & 0.05 \\
Argentina & $40,117,096$ & 0.20 & 0.32 \\
Chile & $19,458,310$ & 0.46 & 0.51 \\
\hline
\end{tabular}

second derivative is: number of citations), numerous non-citable publications do not add to the compound index, leading to the paradox that perceived highly productive ecologists do not appear in the ranking. Secondly, because of the different weights given to the three qualifications in authorship, reputedly productive ecologists that collaborate with many authors but are in the middle of long authorship lines may not show in the ranking.

\section{Conclusions}

Based on Ioannidis et al.'s proposed index of scientific productivity we extract three lessons: (1) It does not pay to publish many papers; what counts is the number of allocites (i.e., self-citations do not add up). (2) Either be single, first, or last author; it does not pay to be in the middle of an authorship line. (3) Even worse it is to be among many co-authors because the $\mathrm{Hm}$ index allocates credits on a per capita basis. The current practice of involving numerous authors in papers published in prestigious journals (aimed at increasing total citations, but not necessarily personal $\mathrm{H}$ index) should be pondered by prospective collaborators, if compound indices such as the one discussed here become commonly applied.

\section{Abbreviations \\ NC: Number of allocites; H: $h$ index; Hm: corrected $h$ index; NCS: single author; NCSF: single + first author; NCSFL: single + first + last author; \\ $\mathrm{CV}$ : coefficient of variation}

\section{Acknowledgments}

We thank FP Ojeda for editorial guidance, Angélica Catalán for help with tables, and Soraya Sade for text edition.

\section{Authors' contributions}

Data analysis: JRR. Manuscript preparation: JRR, FMJ. All authors read and approved the final version of the manuscript.

\section{Funding}

We are grateful to ANID PIA/BASAL FB0002.

\section{Availability of data and materials}

Not applicable.

\section{Declarations}

Ethics approval and consent to participate Not applicable.
Consent for publication

Not applicable.

\section{Competing interests}

The authors have not competing interests.

\section{Author details}

'Laboratorio de Ecología, Departamento de Ciencias Biológicas y Biodiversidad, Universidad de Los Lagos, Campus Osorno, Osorno, Chile.

${ }^{2}$ Center of Applied Ecology and Sustainability (CAPES), Pontificia Universidad Católica de Chile, 8331150 Santiago, Chile.

Received: 21 May 2021 Accepted: 26 July 2021

Published online: 10 August 2021

References

1. Wojciechowski J, Ceschi F, Pareto SCAS, Ribas L, Bezerra LAV, Dittrich J, et al. Latin American contribution to ecology. Anais da Academia Brasileira de Ciencias. 2017;89(4):2663-74. https:/doi.org/10.1590/0001-3765201720160535.

2. Santin DM, Caregnatos SE. Concentración y desigualdad científica en América Latina y el Caribe a principios del siglo XXI: un estudio cienciométrico. Información, Cultura y Sociedad. 2020;43:13-30.

3. Ioannidis JPA, Boyack KW, Baas J. Updated science-wide author databases of standardized citation indicators. PLoS Biol. 2020;18(10):e3000918. https://doi. org/10.1371/journal.pbio.3000918.

4. Schreiber M. A modification of the $h$-index: the $h m$-index accounts for multi-authored manuscripts. Journal of Informetrics. 2008;2(3):211-6. https:// doi.org/10.1016/j.joi.2008.05.001.

5. Jaksic FM, Santelices B. ¿Alguien lee a los ecólogos chilenos? Rev Chil Hist Nat. 1991;64:13-8.

6. Smith MJ, Weinberger C, Bruna EM, Allesina S. The scientific impacts of nations: journal placement and citation performance. PLoS One. 2014;9(10): e10195.

7. Rau JR, Monjeau A, Pizarro JC, Anderson CB. Cuanto más publicamos, menos nos citan. Ecol Austral. 2017a;27(3):385-91. https://doi.org/10.25260/ EA.17.27.3.0.453.

8. Anderson CB, Monjeau A, Rau JR. Knowledge dialogue to attain global scientific excellence and broader social relevance. BioScience. 2015;65(7): 709-17. https://doi.org/10.1093/biosci/biv046.

9. Rau JR, Anderson CB, Pizarro JC, Monjeau A. When more really isn't better: aligning policies and outcomes in ecology. Bull Ecol Soc Am. 2017;98:337-40.

10. Rau JR, Fuentes N. Letters to the director. Interciencia. 2020;45:305.

11. Fontúrbel $\mathrm{FE}$, Vizentin-Bugoni J. Open access article processing charges (APC) may prevent some researchers from publishing in leading journal. Bull Ecol Soc Am. 2021;102(1):e01791.

12. Rossiter MW. The Matthew Matilda effect in science. Soc Stud Sci. 1993; 23(2):325-41. https://doi.org/10.1177/030631293023002004.

13. Tregenza T. Gender bias in the refereeing process? TREE. 2002;17:349-50.

14. Leimu R, Koricheva J. What determines the citation frequency of ecological papers? TREE. 2005;20(1):28-32. https://doi.org/10.1016/j.tree.2004.10.010.

\section{Publisher's Note}

Springer Nature remains neutral with regard to jurisdictional claims in published maps and institutional affiliations.
Ready to submit your research? Choose BMC and benefit from:
- fast, convenient online submission
- thorough peer review by experienced researchers in your field
- rapid publication on acceptance
- support for research data, including large and complex data types
- gold Open Access which fosters wider collaboration and increased citations
- maximum visibility for your research: over $100 \mathrm{M}$ website views per year
At BMC, research is always in progress.
Learn more biomedcentral.com/submissions 